\title{
Giza Zientzietako eta Gizarte Zientzietako abstract-ak, berdinak ote? Euskarazko laburpenen diskurtso-ezaugarriak
}

\section{Are Abstracts in Social Sciences and Humanities the same? Discursive Features of Basque Abstracts}

\author{
Mari Mar Boillos Pereira \\ Universidad del país Vasco / Euskal Herriko Unibertsitatea \\ mariadelmar.boillos@ehu.eus \\ Garbiñe Bereziartua EtXeberria \\ Universidad del país Vasco / Euskal Herriko Unibertsitatea \\ garbine.bereziartua@ehu.eus \\ Recibido: marzo de 2021. Aceptado: mayo de 2021.
}

Laburpena: Laburpen zientifikoak edo abstract-ak garrantzi esanguratsua du esparru akademikoan. Horregatik egin dira hainbat azterlan testu horien egitura prototipikoa hizkuntza eta diziplina desberdinetan ezagutzeko. Azterlan honetan, euskarazko testu horien ezaugarri diskurtsiboak ezagutu nahi dira, baita Gizarte Zientzien eta Giza Zientzien eremukoen artean desberdintasunik ba al dagoen ikusi ere. Horretarako, Uztaro aldizkariaren azken 5 urteetako 99 laburpen aztertu dira Hyland-en eredua jarraituz (2000). Emaitzen arabera, egitura ugari daude eta homogeneotasun orokorra falta da, bai ezagutza-eremu batean eta bai bestean. Hori dela eta, sistematikotasunerantz urratsak emateko beharrari buruz egindako hausnarketak aurkeztuko dira.

Gako-hitzak: Giza Zientziak, Gizarte Zientziak, idazketa akademikoa, laburpen zientifikoak, analisi diskurtsiboa.
Abstract: Scientific summaries or abstracts have a significant importance in the academic field. This is why many studies have been carried out on the prototypical structure of these texts in different languages and disciplines. In this work, we want to know the discursive characteristics of these texts in Basque and also identify the differences between the Social and Human Sciences. For this purpose, the 99 abstracts published in the journal Uztaro in the last five years have been analysed, based on Hyland's model (2000). 
According to the results, there are multiple structures and there is a general lack of homogeneity, both in one and in another discipline. Therefore, reflections will be presented on the need to take steps towards systematization.

Keywords: Social Sciences, Humanities, Academic Writing, abstracts, discursive analysis.

\section{I.- SARRERA}

Unibertsitate-eremuan idazteak komunitate akademikoaren berezko interakzio-moduak menderatzea eta errealitate horretan sortzen diren testu-generoen ezaugarriak ezagutzea eskatzen du. Hortik dator, beste testu-genero batzuen artean, abstract-en azterketari jarri zaion arreta helburu espezifikoak dituzten erretorika- eta hizkuntza-ikasketetan. Testu-genero hori bereziki garrantzitsua da kontuan hartzen bada irakurleak artikulu zientifikoekin duen lehen kontaktua dela eta erabakigarria dela artikulua irakurriko den ala ez erabakitzeko orduan (Piqué-Noguera 2012). Horregatik da garrantzitsua genero horren eraikuntza menderatzea eta balizko irakurleek aurkitu asmo dituzten egituretara egokitzea.

Azterketa honek premisa hori du abiapuntu eta euskararen mundu akademikora garamatza. Historian zehar ezagutzaren zabalpena euskaraz eta hainbat genero diskurtsiboren bidez egin dela frogatuta badago ere (Artetxe 2013), Boillosen eta Bereziartuaren (2020) lanak adierazten du euskaraz idatzitako abstracten tradizioa laburra dela, eta orain ari dela gertatzen euskarazko laburpenak barne hartzen dituzten aldizkarien gorakada esanguratsua. Horrela, lan honen helburua da, beste hizkuntza batzuetan (gaztelania eta inglesa, besteak beste) egin den bezala, Giza eta Gizarte Zientzietako laburpen zientifikoek zer ezaugarri diskurtsibo dituzten (Discourse Analysis) jakitea eta bi ezagutzaeremu horien artean desberdintasunik ba al dagoen ikustea. Horretarako, Uztaro aldizkariaren azken 5 urteetako abstract guztiak aztertu dira. 99 testuri esker, jokabide homogeneorik ba al dagoen eta bi ezagutza-eremu handien artean alde nabarmenik ba ote dagoen egiaztatu ahal izan da.

Helburu horrekin, lan honetan, lehenik eta behin, abstract bat zer den eta egiturazko zer ezaugarri dauzkan aztertuko da. Era berean, gai horri buruzko azterketa garrantzitsuenak berrikusiko dira. Hurrengo atalean, metodologian, azterketaren helburuak, lagina eta datuak aztertzeko prozedura deskribatuko dira. Emaitzen atalean ikerketa-galderei erantzungo zaie eta, azkenik, gure hausnarketak aurkeztuko dira.

\section{II.- MARKO TEORIKOA}

Berrikuspen teoriko honetan abstract edo laburpen zientifiko bat zer den azalduko dugu. Era berean, bere egitura eta antolaketaren inguruan ikertu dena berrikusiko dugu. Azkenik, diziplina desberdinetan eta, zehazki, Gizarte 
Zientzietan eta Giza Zientzietan abstracten ezaugarriei buruz orain arte egon diren emaitzen egoera aurkeztuko dugu. Azterlan honen gaia euskarazko idazketa akademikoa da. Euskararen garapena eta testuinguru akademikoan izan duen bilakaera ezagutzea ezinbestekoa izanik, komenigarria litzateke Boillosek eta Bereziartuak (2020) deskribatzen duten errealitatearen konplexutasuna kontuan hartzea.

\subsection{Abstracta, testu-generoa}

80ko hamarkadaz geroztik, idazketa akademikoak interesa piztu du hizkuntzalaritzaren eta hezkuntzaren eremuan, unibertsitate alorrean ekoizten eta kudeatzen diren testu-generoak aztertzen eta lantzen hasi baitira. Testu-genero kontzeptuaren sortzailea den Bakhtin-en (1979) arabera, testu-generotzat hartzen dira diskurtso-forma estereotipatuak, erabileraren poderioz finkatu direnak eta komunikazio-egoera berberetan egonkortasunez errepikatzen direnak. Horregatik, hiztunek ezagutu eta parteka ditzaketen formak dira, eta haien formatua eta testuingurua identifikatzen dituzte.

Nahiz eta 90eko hamarkadan abstracta komunitate zientifikoak baztertutako testu-generoa izan (Swales 1990), gaur egun ez dago zalantzarik esatean abstractek zientziaren arloan garrantzi nabarmena daukatela. American Psychological Association (2020) erakundearen arabera (aurrerantzean, APA), bai bertako arauen zazpigarren edizioa argitaratzean, bai aurreko edizioetan, laburpenak 250 hitz inguru luze direla arautzen den arren, laburpen horiek ezagutza zabaltzeko lehen tresna bihurtu dira. Testu zientifikoen bilaketak egiten direnean, ikertzaileak —izan adituak edo izan hasiberriak - irakurtzen duten lehenengo testu-zatia laburpena izango da. Hala, testu hori erabakigarria izango da jarraian datorren informazioa irakurriko duten ala ez erabakitzerako orduan (Quintanilla, 2016). Ondorioz, beharrezkoa izango da abstracta ondo idatzita egotea; bestela, artikuluak agian ez du merezi duen arreta jasoko (Piqué-Noguera 2012).

Beraz, berezko entitatea duen testu-genero bat da, bere atzetik doan artikulu zientifikoaren funtsezko ideiak laburbiltzen dituena (Tseng 2011). Helburua, argi dago: jendearen arreta bereganatzea. Horretarako, APAk (2020) uste du abtractak funtsezko lau ezaugarri izan behar dituela. Alde batetik, zehatza izan behar du, hau da, lanaren helburu eta eduki zehatzak islatu behar ditu, ez gehiago, ez gutxiago. Bestetik, beharrezkoa da objektiboa izatea, ez ebaluatzailea, eta, beraz, egilearen edo egileen iritzi pertsonala ez jasotzea. Hirugarrenik, beharrezkoa da koherentea eta irakurgarria/ulergarria izatea. Laburpeneko diskurtsoa argia eta koherentea izan dadin, hobe da orainaldian egotea, eta forma aktiboak lehenesten dira. Azkenik, laburra izan behar du eta perpaus bakoitzak ahalik eta informazio gehien eman behar du.

Abstractaren hartzailea erakarri eta artikulua irakurtzen jarrai dezan lortzeko beharrak genero horren egitura prototipikoa zein den jakiteko interesa piztu du. Hala, azterlan askok adierazi dute testuaren barruan funtzio komunikatiboak dituzten unitate diskurtsibo edo erretoriko desberdinak daudela. Unitate horiei 
moves deitu izan zaie (hemen mugimendu adiera erabiliko dugu). Beste era batera esanda, diskurtsoaren zati identifikagarriak dira, helburu zehatzak dauzkatenak.

Gaur egun arte, asko dira mugimendu horien sekuentzia identifikatzen saiatu diren ikerketak (Weissberg eta Buker 1990, Bhatia 1993, Dos Santos 1996, besteen artean). Hala ere, Hyland-en (2000) lanak izan du arrakastarik handiena. Ingelesezko IPMPrC siglez ezagutzen den eredu honetan, bost moves (mugimendu) dituen egitura bat ezartzen da:

- I, introduction. Zati honetan, azterketaren testuingurua eta izateko arrazoia aurkezten dira.

- P, purpose. Lanaren helburuei, tesiei eta hipotesiei egiten die erreferentzia.

- M, method. Hemen, erabilitako metodoari buruzko informazioa azpimarratzen da: prozedurak, datuak biltzeko tresnak, parte-hartzaileak, etab.

- Pr, product. Ikerketaren emaitzak: «Produktua». Mugimendu honek, askotan, soluzio edo produktuaren ezaugarri edo propietate nagusien deskribapena ere barne hartzen du.

- C, conclusions. Emaitzak artikuluaren irismenetik harago zabaltzeko helburua dute. Azken mugimendu horrek hainbat eduki izan ditzake: emaitzen ondorioak ondorioztatzea, ikerketaren balioa ebaluatzea eta/ edo gomendioak aurkeztea.

Eredu hori erabili izan da arlo horretan argitaratu diren azterlan gehienak egiteko. Hurrengo atalean horietako batzuk aipatzen dira.

\subsection{Abstractak diziplinetan: Gizarte-Zientzien eta Giza-Zientzien kasua}

Laburpenak ez dira beti mugimendu prototipikoz osatuta egon ohi, eta mugimendu horien hurrenkeran ere aldaketak egon daitezke. Horretan, egileen erabakiak sartzen dira jokoan eta, batzuetan, argitaratuko den aldizkariaren gidalerroak. Baina badira mugimendu horien presentziari edo gabeziari eragiten dioten beste irizpide batzuk ere, besteak beste, ezagutza-eremu bakoitzeko idazmoldeak. Testu-genero honen izaerari buruz gehiago jakiteko dagoen interesak hainbat ikerketa-lerro sortu ditu.

Lehenengoak erretorika kontrastatzailean (Contrastive Rhetoric) du jatorria (Kaplan 1966) eta zeinahi hizkuntzatan idatzitako abstracten arteko ezberdintasunak aztertzea du helburu nagusi. Horrela, normalean ingelesa hartzen da ardatz gisa, esparru akademikoan nagusi den hizkuntza delako (Laborde 2011), eta hizkuntza horretako abstractak beste hizkuntza batzuetan argitaratutakoekin alderatzen dira (Alotaibi 2015, Zanina 2017, besteen artean). Ikerketa horiek erakutsi dute mugimendu batzuen edo besteen lehentasuna lana idazten den hizkuntzaren araberakoa izan daitekeela. Beste ikerketa batzuek egileen ama-hizkuntzan jartzen dute arreta. Ikertzaileen ama-hizkuntza ingelesa denean edo ikertzaileen ama-hizkuntza ingelesa ez den beste hizkuntza bat 
denean abstractetan desberdintasunak agertzen diren edo berdin egituratzen diren jakin nahi da (Friginal eta Mustafa 2016, Al-Khasawneh 2017, besteen artean). Alde horretatik, portaerak ezberdinak direla ikusten da eta azterlan horien emaitzak baliagarriak dira ama-hizkuntza ingelesa ez duten egileek ingelesezko testu zientifikoak idaztean dituzten zailtasunak ezagutzeko eta esku-hartze didaktikoak diseinatzen laguntzen du. Horiez gain, hain ohikoak ez badira ere, badaude lanak kalitate zientifiko handiko aldizkarietan argitaratzen diren abstracten eta ospe gutxiagoko aldizkarietan argitaratzen diren abstracten izaerak alderatzen dituztenak ere (Oneplee 2008, El Dakhs 2018, besteen artean). Aldizkari ospetsuenetan, interes handiagoa ikusten da emaitzen atalean sarrerarenean baino. Era berean, adituek eta neofitoek testu horien idazketa premisa beretatik jorratzen duten ikertzeko interesa ere badago (Menezes 2013, Ansarifar et al. 2018, besteen artean).

Hala ere, azken hamarkadetan gorabidean dauden azterlanen artean kokatzen dira ezagutza-eremu desberdinetan sortzen diren abstracten arteko alderaketak egiten dituztenak. Azterlan horiek Hizkuntzak Berariazko Helburuetarako izeneko adarretik sortzen dira (Languages for Specific Purposes), eta hainbat diziplinatako abstracten deskribapenean eta/edo konparazioan jartzen dute interesa. Onartzen da komunitate akademiko bakoitzak bere interakzio-moduak dituela eta, beraz, desberdintasunak egongo direla adar baten eta bestearen artean (Samraj 2008, Ibáñez et al. 2015, besteen artean). Ikerketa-ildo horren barruko azterlanek hainbat alderditan jartzen dute arreta. Kasu batzuetan, diziplina bakar baten berezitasunak aztertzen dira (Hizkuntzalaritza - Lores 2004); beste batzuetan, berriz, elkarrengandik hurbilago (Hizuntzalaritza Aplikatua eta Ingelesa Bigarren Hizkuntza -Al-Shujairi et al. 2016) edo urrunago (Hizkuntzalaritza Aplikatua, Kimika Aplikatua eta Matematika Aplikatura - Darabad 2016) dauden diziplinen arteko konparazio-azterketak egin ohi dira. Azterlan horietan ikusten da arlo bereko testuen artean ezaugarri ohikoagoak daudela, baina, bestela ere, jokabide homogeneoak daudela.

Gizarte Zientzien eta Giza Zientzien arloei dagokienez, badirudi ez dagoela arlo handi horien ezaugarriak orokorrean jorratzen dituen azterlanik. Aitzitik, badira ikerketa batzuk jakintza-arlo horietako azpi-diziplinetako abstracten azterketan zentratzen direnak. Egia da garatu diren lan guztiak ezin direla laburbildu, baina azken bost urteetako lan garrantzitsuenetako batzuetan jarriko dugu fokua, hainbat azpi-diziplinatako emaitzen ikuspegi orokorra lortzeko.

Humanitateei dagokienez, badirudi Hizkuntzalaritzak jaso duela arreta gehien. Khansari et al.-ek (2016) Hizkuntzalaritzako aldizkarien ingelesezko 130 abstract aztertu dituzte, jokabide homogeneorik ba al dagoen ikusteko. Hala, batetik, egiaztatzen dute abstract gehienek sarrera-metodoa-emaitzaeztabaida egitura jarraitzen dutela, eta, bestetik, 'sarrera' atalak duela pisurik handiena. Izan ere, batzuetan behin baino gehiagotan agertzen da atal hori. Can et al. (2016) ez datoz bat azken ideia horrekin; izan ere, ikusten dute English for Specific Purposes aldizkarian 2011 eta 2013 artean izandako 50 abstractetan, lehentasunez, helburuei, metodologiari eta emaitzei erreparatzen zaiela. Aitzitik, lanen erdiek ez dituzte sarrera eta eztabaida atalak. Azkenik, eta horretan bat 
datoz Khansari et al. (2016) eta Can et al. (2016), mugimenduen hurrenkeran irregulartasunak hautematen direla ikusi dute, oro har.

Literaturaren kasuan, Tankók (2017) eragin handiko nazioarteko aldizkarietako 135 testu berrikusi zituen eta egiaztatu zuen, oro har, abstracten egitura eta artikuluaren sarrerena gainjarri egiten direla. Halaber, egileek helburuei eta emaitzei lehentasuna ematen dietela eta gaia lan-esparru baten barruan aurkezten saiatzen direla egiaztatu du. Zentzu horretan, badirudi bat egiten dutela Modern Language Association estilo liburuak (MLA 2016) abstract-en ezaugarriei buruz dioenarekin (Gibaldi 2008). Azkenik, arloko patroi propiorik ez dagoela ondorioztatuz, oso kritiko agertzen da egilea; esaten du Natur Zientzien esparruko ekoizpenei balio sozio-ekonomikoa ematen zaienez, horrek eramaten dituela esparru horretako autoreak ekoizpen zientifikoen laburpenetan ere patroi eraginkorrak jarraitzera eta horrelakorik ez dela gertatzen literaturaren eremuan.

Hizkuntzalaritza Literaturarekin alderatzen duen azterlan berri batean (Bhatti et al. 2019) ondorioztatzen denez, ez dago alde adierazgarririk bi diziplinetako abstracten artean. Maila makro edo estrukturalean, bi kasuetan gaia kokatzen da eta asmoa eta emaitzarik garrantzitsuenak azpimarratzen dira. Badirudi gainerako mugimenduek ez dutela hainbesteko pisurik.

Gizarte Zientziei dagokienez, Blancoren (2017b) lana Venezuelako Hezkuntzako zortzi aldizkaritan gaztelaniaz argitaratutako abstracten azterke$\tan$ zentratzen da. 75 laburpenetako mugimenduen analisiak dio laburpen gehienek hiru mugimendu edo gehiago dituztela eta 'emaitzak' kategoria aztertutako testuen erdietan bakarrik agertzen dela; eta, oro har, esku-hartze profesionala gauzatu duten lanak direla. Halaber, ikusten da ez dagoela estruktura nagusirik, eta, beraz, aldizkarien laburpenen arteko portaerak heterogeneoak direla. Egile horrek berak (Blanco 2017a) 254 laburpenen konparazio diakronikoa egin zuen 1997 eta 2016 artean, Venezuelako hezkuntza-aldizkarietan berriz ere. Azterlanean ikusten da egituretan gero eta egonkortasun handiagoa dagoela eta 'emaitzak' mugimenduaren presentzia gero eta handiagoa dela.

Quintanillak (2016) egindako lanak ere hezkuntza arloa du ardatz eta, horretarako, arlo horretako aldizkari baten 50 testuren egitura aztertu du. Berak ere jokabide heterogeneoa ikusten du eta komunitate akademiko-zientifiko honen barruan gaitasun diskurtsiboak indartzeko beharra azpimarratzen du. Beste diziplina bati begira jarrita, badirudi homogeneotasuna badagoela politikari buruzko lanen kasuan. Eremu honetako Irango aldizkarietako 120 testuren azterketak soilik 'helburuak' eta 'metodoa' atalen agerpenerako joera erakusten du. Beste hiru mugimenduek askoz maiztasun txikiagoa dute (Seyed eta Shamala, 2019).

Laburbilduz, berrikuspen teoriko honetan abstractak testu-genero akademiko gisa duen garrantzia nabarmendu dugu. Gainera, testu horien egiturazko ezaugarriak ikuspegi desberdinetatik aztertzeko interesa egiaztatu ahal izan dugu. Aztertutako azterlanetan, ezagutza-eremu batetik bestera zer desberdintasun dauden ikusi dugu. Berrikusi ditugun ikerketetan egiaztatu da Giza eta Gizarte Zientzien kasuan ez dagoela jokabide homogeneorik, ez ezagutzaeremu horien artean eta ez ezagutza-eremu horietako bakoitzaren baitan idazten 
diren laburpenetan. Hala ere, horiek guztiak beste hizkuntza batzuetan zentratu diren ikasketak dira, eta, esan bezala, hizkuntza faktore erabakigarria da testugenero hori egituratzeko orduan. Interesgarria da, beraz, euskararen kasuan zer gertatzen den ikustea.

\section{III.- METODOLOGIA}

\subsection{Helburua eta ikerketa-galderak}

Esku-artean daukagun lana ikerketa zabalagoko baten parte da. Ikerketa horren helburu nagusia euskara akademikoaren ezaugarriak ezagutzea da, diskurtsiboak zein linguistikoak. Horretarako, azpi-helburuetako bat euskarazko abstracten azterketa diskurtsiboa egitea da, hau da, abstract horiek osatzen dituzten mugimendu erretorikoak aztertzea. Kasu honetan, aurkezten den ikerketa esplorazio-ikerketa bat da; testuen azterketa egin da, Giza-Zientzietako laburpenen eta Gizarte-Zientzietako laburpenen artean desberdintasunik ba al dagoen ikusi ahal izateko.

Helburu hori lortzeko bi ikerketa-galdera mahaigaineratu ditugu:

1. Zeintzuk dira Uztaro aldizkariak argitaratutako euskarazko abstracten ezaugarri diskurtsiboak? Alderik ba al dago Giza Zientzietako eta Gizarte Zientzietako abstracten artean?

2. Zer egitura dauzkate abstract horiek osatzen dituzten mugimendu erretorikoek? Alderik ba al dago Giza Zientzietako eta Gizarte Zientzietako abstracten artean?

\subsection{Lagina}

Ikerketa hau egiteko Uztaro aldizkarian jarri dugu begia. Kasu honetan gure helburua bi ezagutza-eremutako lanen euskarazko laburpenak alderatzea izaki, horretarako abagune aproposa eskaintzen du Uztarok. Bere webgunean jasota dagoen moduan, euskara hutsezko aldizkari zientifikoa da eta Giza eta Gizarte Zientziei buruzko artikuluak argitaratzen dira (https://www.uztaro.eus/). Horrenbestez, euskarak eremu zientifikoan daukan presentzia aztertzeko egindako oinarrizko ikerketa bat gauzatzeko erabilitako corpusa kontuan hartuta (Boillos eta Bereziartua 2020), eskuartean dugun lana egiteko ezaugarri egokiak eskaintzen zituen Uztaro aldizkariak eta hori izan da aukeratzeko arrazoia.

Uztaro aldizkaria Udako Euskal Unibertsitatearen (UEU) baitan sortu zen 1990. urtean. 1996. urtera arte aldizkariaren hiru zenbaki kaleratu izan ziren urtean, baina hortik aurrera urtean lau zenbaki argitaratzen hasi ziren, hiruhilabetekari bihurtuz. Aldizkariaren webgunean zehazten denez, zenbaki bakoitza 125 orrialdekoa da batez beste.

Aldizkariak betetzen dituen kalitate-adierazleei dagokienez, hainbat zerrenda, aurkibide eta datu-basetan dago, esaterako hauetan: Erih PLUS, CIRC (C), 
DICE (C), RESH (C) eta Latindex v.1.0n irizpide guztiak betetzen ditu (33tik 33). Ondorioz, bere lanak kanpo-ebaluazio itsu bikoitzarekin berrikusten dituen aldizkari bat da, eta kanpoko erredakzio-kontseilua du. Ezaugarri guzti horiek direla eta, euskaraz argitaratzen diren aldizkarien artean kalitate indize onenak dituzten aldizkarien artean aurkitzen da (Boillos eta Bereziartua 2020). Arrazoi horiek guztiak direla-eta, aldizkari hau testuinguru egokia da arlo horietan kalitatezko lan zientifikoen abstract horiek aztertzeko.

Ikerketa hau egiteko lagina Uztaro aldizkarian 2015-2019 urteen artean argitaratu diren lanen euskarazko laburpenek osatu dute, guztira 99 abstract. Hauek dira zehazki lagin hori aukeratu izanaren arrazoiak: batetik, euskarazko argitalpen zientifikoen kopurua gorantz doa azken urteetan (Boillos eta Bereziartua 2020) eta ahalik eta testurik berrienak aztertzea erabaki da; eta, bestetik, artikulu zientifikoen laburpenen egitura diskurtsiboa ikertu duten beste azterlanetako laginen kopuruak kontuan hartu dira eta alderagarri izateko aukera ematen duen kopurua aztertzeko hautua egin da.

Laburpen horiek ezagutza-eremuka banatu ditugu eta, horretarako, bi iturri hartu ditugu erreferentziatzat: (1) Uztaro aldizkariak zehazten du argitaratutako lan bakoitza zein diziplinatan kokatzen duen; eta (2) ezagutza-eremu bateko eta besteko diziplinak bereizteko Unibasq-eko sailkapena hartu dugu kontuan. 1. taulan ikus dezakegu, batetik, urte bakoitzean guztira zenbat lan argitaratu diren; eta, bestetik, urte bakoitzean ezagutza-eremu bakoitzeko zenbat lan argitaratu diren:

I. TAULA. 2OI5-2OI9 URTE-TARTEAN UZTARO ALDIZKARIAN ARGITARATU ZIREN LANEN ETA EUSKARAZKO ABSTRACTEN KOPURUAK EZAGUTZA-EREMUKA ETA URTEZ URTE (N ETA \%). ITURRIA: AUTOREEK SORTUA.

\begin{tabular}{|l|c|c|c|c|c|}
\hline \multirow{2}{*}{ Urteak } & \multirow{2}{*}{$\begin{array}{c}\text { Artikuluak } \\
\text { guztira }\end{array}$} & \multicolumn{2}{c|}{$\begin{array}{c}\text { Giza-Zientzietako } \\
\text { abstractak }\end{array}$} & \multicolumn{2}{c|}{$\begin{array}{c}\text { Gizarte-Zientzietako } \\
\text { abstractak }\end{array}$} \\
\cline { 3 - 6 } & & $\mathbf{n}$ & $\boldsymbol{1}$ & $\mathbf{n}$ & $\%$ \\
\hline 2015 & 21,0 & 5,0 & 23,8 & 16,0 & 76,1 \\
\hline 2016 & 18,0 & 5,0 & 27,7 & 13,0 & 72,2 \\
\hline 2017 & 20,0 & 8,0 & 40,0 & 12,0 & 60,0 \\
\hline 2018 & 19,0 & 1,0 & 5,2 & 18,0 & 94,7 \\
\hline 2019 & 21,0 & 7,0 & 33,3 & 14,0 & 66,6 \\
\hline Guztira & 99,0 & 26,0 & 26,2 & 73,0 & 73,7 \\
\hline Batezbestekoak & 19,8 & 5,2 & - & 14,6 & - \\
\hline
\end{tabular}

Taulak erakusten duenez, 2015-2019 urteen artean guztira 99 lan argitaratu ziren Uztaro aldizkarian, urtean ia 20 lan $(19,8)$ batez beste. Ezagutza-eremu 
bati eta besteari begira jarrita, Giza Zientzietako lanen bateko hiru dira Gizarte Zientzietakoak (\% 26,2 eta \% 73,7, hurrenez hurren).

Uztaron beren lana argitaratu nahi duten egileentzako oharrak agertzen dira webgunean eta hau da lan horien laburpenei buruz zehazten dena: «Lanarekin batera, 100 eta 150 hitz arteko laburpena ere igorriko da, euskaraz eta ingelesez, eta izenburuaren ingelesezko itzulpena» (https://www.uztaro.eus/).

\subsection{Analisiaren prozedura eta deskribapena}

Orri hauetan aurkezten dugun ikerketa egiteko jarraitu ditugun urratsak deskribatuko ditugu jarraian. Lehenik eta behin, aztertu ditugun laburpenen corpusa osatu dugu, ezagutza-eremu bakoitzeko laburpenak bereiziz. Behin hori egindakoan, ikerketa-galdera bakoitzari erantzuteko berariazko analisiak egin ditugu.

Lehenengo ikerketa-galderari erantzuteko, testuen analisi kuantitatiboa egin dugu. Testu bakoitza ANALHITZA prozesadore informatikoarekin aztertu dugu (Otegi, Imaz, Díaz de Ilarraza, Iruskieta eta Uria 2017) eta hainbat elementuren datu estatistiko deskribatzaileak kalkulatu ditugu: abstract bakoitzeko hizkiak, hitzak edo tokenak, lema ${ }^{1}$ motak, eta esaldiak. Giza Zientzietako eta Gizarte Zientzietako testuen arteko alderaketa egiteko t-student kalkuluak egin ditugu. Analisi horiek egiteko SPSS 18 programaz baliatu gara. Orain arte ez dira gisa horretako analisiak egin izan diziplina honetan eta ez daukagu aukerarik beste ikerketekin alderaketak egiteko, baina diziplinartekotasunari balioa ematen zaion garaiotan eta prozesadore informatikoak eskura izanda, etorkizunean gai hau aztertzeko egin ahal diren beste ikerketa batzuetarako abiapuntu edo helduleku bat ezarri nahi izan dugu.

Bigarrengo ikerketa-galderari erantzuteko corpuseko laburpenak osatzen dituzten mugimendu erretorikoak analizatu ditugu, atal teorikoan aurkeztu dugun Hylandek (2000) proposatutako eredua oinarri hartuta. Horretarako hiru fenomeno aztertu ditugu: (1) laburpenetan agertzen diren mugimenduak zeintzuk diren; (2) mugimendu bakoitza zer maiztasunetan agertzen den; eta (3) laburpenetan mugimendu horiek zer hurrenkeratan agertzen diren (flow of movements).

Egin diren analisietan aztertzaileen arteko fidagarritasuna bermatzeko (inter-rater reliability) neurriak hartu dira. Autore bakoitzak modu independentean egin ditu analisiak eta ondoren emaitzak erkatu dira; bat-etortzerik ez zegoen kasuetan, kasu horiek berriro aztertu dira. bakoitza.

${ }^{1}$ Hizkuntzalaritzaren baitan lexikoari dagokio: unitate semantikoa, hiztegi batetako sarrera 


\section{IV.- EMAITZAK}

\section{1. ikerketa-galdera: Zeintzuk dira Uztaro aldizkariak argitaratutako euskarazko abstracten ezaugarri diskurtsiboak? Alderik ba al dago Giza Zientzietako eta Gizarte Zientzietako abstracten artean?}

Lan honen lagina hobeto ezagutzeko, lehenik eta behin, abstracten analisi kuantitatibo orokorra egin da. Azterketa horren emaitzak 2. taulan bildu ditugu.

2. TAUla. CORPUSEKo TESTUEN EZAUgARRI KUANTITATIBOEN BATEZBESTEKOAK ETA DESBIDERATZE ESTANDARRAK EZAGUTZA-EREMUKA. ITURRIA: AUTOREEK SORTUA.

\begin{tabular}{|l|c|c|c|c|}
\cline { 2 - 5 } \multicolumn{1}{c|}{} & \multicolumn{2}{c|}{ Giza Zientziak (n= 26) } & \multicolumn{2}{c|}{ Gizarte Zientziak (n = 73) } \\
\cline { 2 - 5 } \multicolumn{1}{c|}{} & Batezbestekoa & \multicolumn{1}{c|}{ SD } & Batezbestekoa & \multicolumn{1}{c|}{ SD } \\
\hline Hizki kopurua & 716,81 & 215,813 & 723,23 & 173,770 \\
\hline Hitz/token kopurua & 96,04 & 30,880 & 94,92 & 23,846 \\
\hline Lema motak & 68,04 & 18,264 & 67,37 & 14,773 \\
\hline Esaldi kopurua & 5,12 & 2,046 & 5,44 & 1,958 \\
\hline Hitz/esaldi batezbestekoa & 19,35 & 4,534 & 18,07 & 4,817 \\
\hline
\end{tabular}

Azterlan honetako corpusaren baitako Giza Zientzietako laburpenak batez beste 716,81 hizkiz osatu dira (SD=215,8), eta Gizarte Zientzietakoak, berriz, 723,23 hizkiz $(\mathrm{SD}=173,7)$. Batzuen eta besteen desbideratze estandarrek adierazten dute batezbesteko horretatik aldentzen diren testuak ere badaudela, beraz, testuen luzera ez da homogeneoa corpuseko idatzien artean, ez Giza Zientzietako laburpenetan eta ez Gizarte Zientzietakoetan.

Testuetako hitz kopuruekin ere joera berbera gertatzen da: Giza Zientzietako laburpenak batez beste 96,04 hitzez osatu dira $(S D=30,8)$ eta Gizarte Zientzietakoak 94,92 hitzez $(\mathrm{SD}=23,8)$. Aztertutako laburpenetako hiztegiaren aniztasunari erreparatuta, lema moten kopurua batez beste 68,04 da Giza Zientzietako laburpenetan eta 67,37 Gizarte Zientzietakoetan.

Esaldiei begira jarrita, Giza Zientzietako laburpenek batez beste 5,12 esaldi dauzkate $(\mathrm{SD}=2,04)$; Gizarte Zientzietakoek 5,44 $(\mathrm{SD}=1,9)$. Eta esaldi horietako bakoitzak 19,3 hitz ( $\mathrm{SD}=4,5)$ biltzen ditu Giza Zientzietako laburpenetan; 18,07 hitz $(\mathrm{SD}=4,8)$ Gizarte Zientzietakoetan.

Orain artean ezagutza-eremu bateko eta besteko emaitzak bereizita aurkeztu ditugu eta, begiratu batean, badirudi batzuetatik besteetara alderik ez dagoela. Hala ere, alde hori estatistikoki esanguratsua den ikusi dugu t-student kalkulatuta eta emaitzak 3. taulan jaso ditugu: 
3. TAUlA. CORPUSEKO TESTUETAN BI EZAGUTZA-EREMUETAKO TESTUEN EZAUGARRI KUANTITATIBOEN ALDERAKETA: LAGIN INDEPENDENTEENTZAKO T-STUDENT PROBAREN EMAITZAK. ITURRIA: AUTOREEK SORTUA.

\begin{tabular}{|l|c|c|}
\cline { 2 - 3 } \multicolumn{1}{c|}{} & Levene-ren proba & Esanguratsutasun laterala \\
\hline Hizki kopurua &, 216 &, 880 \\
\hline Hitz/token kopurua &, 161 &, 850 \\
\hline Lema motak &, 334 &, 853 \\
\hline Esaldi kopurua &, 872 &, 323 \\
\hline Hitz/esaldi batezbestekoa &, 668 &, 241 \\
\hline
\end{tabular}

Levene-ren proba eginda lortutako datuek erakusten dute ezagutza-eremu bateko eta besteko datuen artean ez dagoela desberdintasun estatistiko esanguratsurik. Eta esanguratsutasun lateralari buruzko datuek ere gauza bera berresten dute. Hau da, ez dago diziplina bakoitzaren ezaugarri bereizgarririk.

2. ikerketa-galdera: Zer egitura dauzkate abstract horiek osatzen dituzten mugimendu erretorikoek? Alderik ba al dago Giza Zientzietako eta Gizarte Zientzietako abstracten artean?

Azterlan hau egiteko erabili dugun corpuseko abstracten mugimendu erretorikoen egiturei buruz hitz egin aurretik, mugimendu horiei buruzko zenbait datu emanaz hasiko gara. Lehenik eta behin, corpusean identifikatu ditugun mugimenduei buruz hitz egingo dugu. Ondoren, corpuseko laburpenak zenbat mugimenduz osatuak dauden ikusiko dugu. Segidan, mugimendu bakoitza zenbat testutan aurkitu dugun esango dugu. Eta, amaitzeko, corpuseko laburpenetan aurkitu ditugun mugimendu-egiturei buruzko datuak aurkeztuko ditugu.

Aurrez esan bezala, azterketa hau egiteko Hylanden (2000) proposamena hartu dugu oinarri. Hylandek bost mugimendu prototipiko proposatzen ditu abstractak osatzeko eta gure corpusean bost mugimendu horiek aurkitu ditugu, baina proposamen horretatik kanpo dauden joerak ere identifikatu ditugu.

Lehenik, Hylandek proposatzen dituen mugimenduez gain beste mugimendu bat agertzen dela ikusi dugu, Antolaketa izenez bataiatu duguna. Mugimendu horretan ondoren aurkezten den lanaren egitura deskribatzen da, baina ez da edukien berri ematen. Corpuseko testuen arteko 10etan (\% 10,1; Giza Zientzietako testuen arteko \% 23,07 eta Gizarte Zientzietako testuen arteko \% 5,4) agertzen da Antolaketa izendatu dugun mugimendua. Eta, kasu gehienetan, Hylanden proposameneko beste mugimendu batzuekin konbinatuta agertzen da. Hona hemen horren adibide den testu bat:

(P) Egungo erregimen demokratikoen krisia oinarri harturik, artikulu honek Platonen pentsamendu politikoak eduki dezakeen gaurkotasun eta garrantziaz egiten du gogoeta. (Ant) Lehenik eta behin, egungo egoera politikoaren 
gainbegiratu orokor bat eskaintzen du, Platonen teoria politikoa eta, oro har, demokratikoa ez den pentsamendu politiko oro era arinean gaitzesten direla nabarmenduz, totalitaristak direlako aitzakiarekin. Jarraian, atenastarraren teoria politikoaren oinarri teorikoak agerian uzten dira, ostera ideologia demokratikoaren -Periklesen garaikoaren zein gaur egungoaren- oinarriekin alderatuta erabat bestelakoak direla agerian utziz. Bi ikuspegiek proposatutako ildoa desberdina da, hain zuzen ere, haien printzipioak erabat bestelakoak direlako. Azkenik, analisiaren ondorio moduan, Platonen, baina baita demokratikoak ez direnen, hausnarketa politikoak tentuz aztertzea ikuspegi demokratikoa defendatzen dutenei arrunt mesedegarria suerta dakiekeela nabarmentzen da, batez ere, teoria demokratikoaren oinarriak birpentsatzeko aukera eskaintzen baitu. [GZ.17.07]

Bigarrenik, testu batzuk Hylanden proposameneko zenbait mugimenduz osatuta daude, baina mugimendu horietakoren bat errepikatu egiten da. Hori gertatzen da corpuseko testuen arteko $11 \tan (\%$ 11,1). Ezagutza-eremu bakoitzeko testuetan gertatzen dena erakusten du 4. taulak:

\section{Taula. Corpuseko testuetan errepiKatutako mugimenduaK eZagutZa- EREMUKA (N ETA \%). ITURRIA: AUTOREEK SORTUA.}

\begin{tabular}{|l|r|r|r|r|}
\cline { 2 - 5 } \multicolumn{1}{c|}{} & \multicolumn{2}{c|}{ Giza Zientziak } & \multicolumn{2}{c|}{ Gizarte Zientziak } \\
\cline { 2 - 5 } \multicolumn{1}{c|}{} & n & \multicolumn{1}{c|}{$\%$} & n & \multicolumn{1}{c|}{$\%$} \\
\hline P mugimendua errepikatuta & 3 & 11,5 & 5 & 6,8 \\
\hline M mugimendua errepikatuta & 0 & 0 & 2 & 2,7 \\
\hline I mugimendua errepikatuta & 0 & 0 & 1 & 1,3 \\
\hline Errepikatutako mugimenduak guztira & 3 & 11,5 & 8 & 10,9 \\
\hline
\end{tabular}

Ikusten dugunez, mugimenduak errepikatu diren kasu gehienetan $\mathrm{P}$ (Helburua) mugimendua izan da errepikatu dena. Giza Zientziei dagokienez, hori gertatu den 3 kasuetan (\% 11,5); Gizarte Zientziei dagokienez, errepikapenak egon diren 5 kasutan $(\%$ 6,8). Baina Gizarte Zientzietako bi testutan M (Metodoa) mugimendua izan da errepikatu dena eta beste kasu batean I (Sarrera) mugimedua. Mugimenduak errepikatu diren testu baten adibidea ikus dezakegu segidan:

(P) Artikulu honen helburua Mikel Laboaz esparru zientifikoan idatzi denari buruzko ikuspegi orokorra ematea da, arreta berezia eskainiz kantariaren alde esperimentalaz esaten denari. (M) Horretarako, euskal komunitate zientifikoaren datubasea, Inguma, hartuko da erreferentzia nagusitzat eta bertan biltzen diren Mikel Laboari buruzko euskarazko lanen analisia egingo da. (P) Analisi bibliografiko honen bidez, Laboak euskal kulturgintzari egindako 
ekarpen berritzailea azaleratu asmo da, bere musikagintzaz orain arte egin diren hausnarketak osatuz. [GR.19.07]

Hirugarrenik, testu batzuk I (Sarrera) mugimendua bakarrik daukate. Hori gertatzen da corpuseko 6 testutan (\% 6,06), Giza Zientzietako 2 eta Gizarte zientzietako 4; esate baterako, hemen:

(I) Kyotoko Protokoloa ordezkatuko duen akordio loteslea lortzeko negoziazioak 2007an hasi ziren. 2009ko Kopenhageko Konferentziaren porrotaren ondoren, negoziazioak bertan behera geratu ziren, eta ez zen ia aurrerapenik eman hurrengo bileretan. EBren lidergoa klima-aldaketaren aurkako borrokan, mundu-aliantza batean ahalik eta herrialde gehien bateratzeko ahaleginetan, ahuldu egin zen, AEBk gero eta protagonismo handiagoa hartu zuelako jarrera pasiboarekin eta oztopatzailearekin-, bai eta Txinak ere. Nahiz eta EBk berriro sustatu zituen negoziazioak, badirudi Parisko Akordioa posible izan zela AEBren eta Txinaren inplikazio handiagatik; horrek aldi berean dakar askok zalantzan jartzea benetan emaitza arrakastatsua izango dela. [GR.17.08]

Corpuseko testuen mugimendu-kopuruari dagokionez, esan bezala, Hylandek 5 mugimenduz osatutako egitura proposatu zuen. Gure kasuan, mugimendu bakarraz osatutako testuetatik hasi eta 5 mugimendu edukitzeraino iristen diren testuak identifikatu ditugu. 5. taulan aurkezten da informazio hori²:

5. Taula. Corpuseko testuen baitan dauden mugimendu kopuruak eta HORIETAKO BAKOITZA ZENBAT TESTUTAN IDENTIFIKATU DUGUN (N ETA \%). ITURRIA: AUTOREEK SORTUA.

\begin{tabular}{|c|r|r|r|r|r|r|}
\hline \multirow{2}{*}{ Mugimendu kopurua } & \multicolumn{2}{|c|}{ Guztiak } & \multicolumn{2}{c|}{ Giza-Zientziak } & \multicolumn{2}{c|}{ Gizarte-Zientziak } \\
\cline { 2 - 7 } & \multicolumn{1}{c|}{$\mathrm{n}$} & \multicolumn{1}{c|}{$\%$} & $\mathrm{n}$ & \multicolumn{1}{c|}{$\%$} & $\mathrm{n}$ & \multicolumn{1}{c|}{$\%$} \\
\hline 1 & 7 & 7,07 & 3 & 11,5 & 4 & 5,4 \\
\hline 2 & 26 & 26,2 & 7 & 26,9 & 19 & 26,0 \\
\hline 3 & 39 & 39,3 & 13 & 50,0 & 26 & 35,0 \\
\hline 4 & 24 & 24,2 & 2 & 7,6 & 22 & 30,1 \\
\hline 5 & 3 & 3,03 & 1 & 3,8 & 2 & 2,7 \\
\hline Guztira & 99 & 100,0 & 26 & 100,0 & 73 & 100,0 \\
\hline
\end{tabular}

Ikus dezakegunez, corpuseko testu guztiak batera hartzen baldin baditugu, laburpen gehienak 3 mugimenduz osatutakoak dira (\% 39,3); horien atzetik 2 mugimenduz $(\% 26,2)$ eta 4 mugimenduz $(\% 24,2)$ osatutakoak daude; eta bakanak dira mugimendu bakarraz $(\% 7,07)$ edo bost mugimenduz $(\% 3,03)$ osatutakoak.

2 Testu berean errepikatzen diren mugimenduak ez ditugu birritan kontatu, mugimendu bakoitza zenbat laburpenetan agertu den, baizik. 
Baina ezagutza-eremu bakoitzari erreparatzen badiogu, Giza Zientzien esparruko laburpenen erdia (\% 50) da hiru mugimenduz osatutakoa eta beste laurdena pasa $(\% 26,9)$ bi mugimenduz osatutakoa; Gizarte Zientzien esparruko laburpenetan banaketa berdintsuagoa da 2, 3 eta 4 mugimenduz osatutako testuen artean (\% 26, \% 35 eta \% 30,1, hurrenez hurren).

Mugimendu bakoitzaren agerpenari begira jarrita, 1. grafikoak ematen du datu horien berri:

I. Grafikoa. Mugimendu bakoitzaren agerpena Corpuseko testuetan EZAGUTZA-EREMUKA (\%). ITURRIA: AUTOREEK SORTUA.

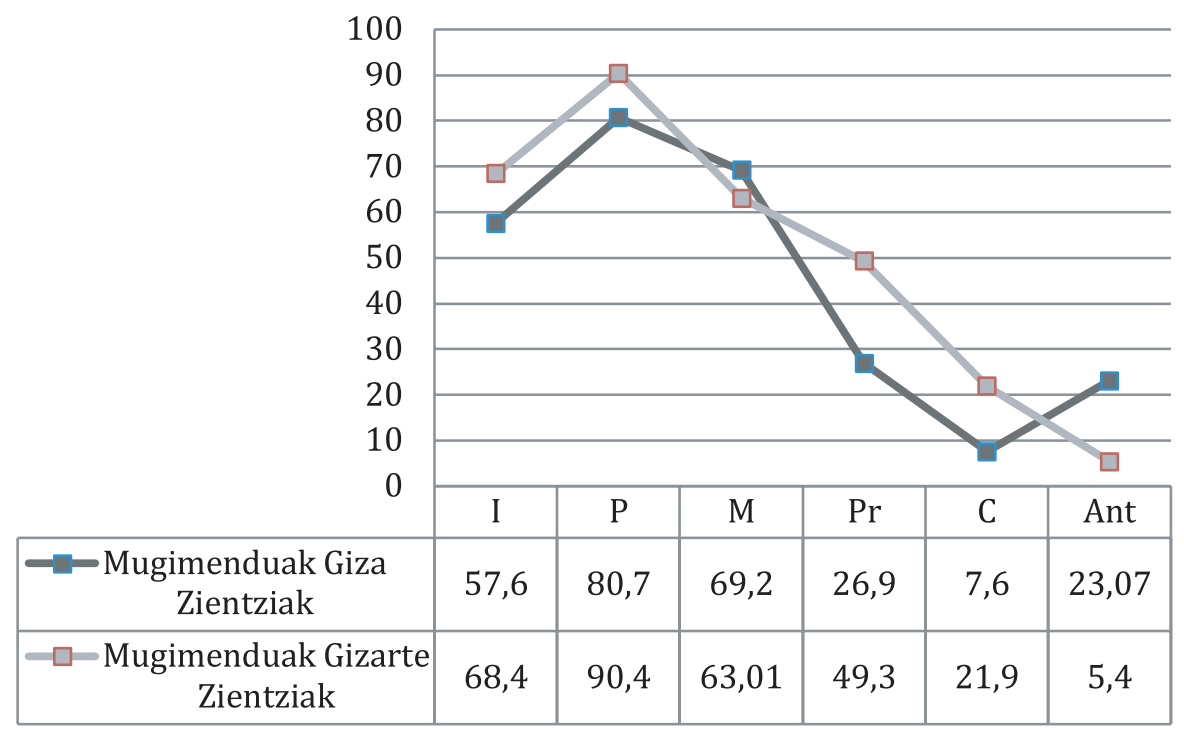

Corpuseko testuetan gehien agertu den mugimendua P (Helburua) izan da, bai Giza Zientzietako laburpenetan $(\% 90,4)$ eta bai Gizarte Zientzietako laburpenetan (\% 80,7). Horren atzetik presentzia gehien daukatenak M (Metodoa) eta I (Sarrera) mugimenduak dira, bai ezagutza-eremu batean eta bai bestean testuen erdia baino gehiagotan agertzen dira. Pr (Emaitzak) mugimendua etorriko litzateke jarraian, eta bere presentzia altuagoa da Gizarte Zientzien eremuko testuetan (\% 49,3) Giza Zientzietakoetan baino (\% 26,9). Gutxien agertu diren mugimenduak Antolaketa eta C (Ondorioak) izan dira bi ezagutza-eremuetan. Hala ere, bi mugimendu horien agerpenkopuruak alderantzizkatu egiten dira bi ezagutza-eremuetan: C (Ondorioak) mugimenduak presentzia handiagoa dauka Gizarte Zientzietan (\% 21,9) Giza Zientzietan $(\% 7,6)$ baino; eta Antolaketa mugimendua gehiago agertzen da Giza Zientzietako testuetan (\% 23,07) Gizarte Zientzietakoetan $(\% 5,4)$ baino. 
Mugimenduei buruzko informazio orokorra eman dugu orain artean, baina mahaigaineratu dugun ikerketa-galderari erantzuna ematen ahaleginduko gara ondorengo lerroetan. Hylanden I-P-M-Pr-C egitura prototipikoari dagokionez, gure corpuseko 3 testutan aurkitu ditugu 5 mugimenduok batera: Giza Zientzietako testu batean $(\%$ 3,8) eta Gizarte Zientzietako bi testutan (\% 2,7). Hala ere, gure corpusean 5 mugimendu horiek dauzkaten testu guztietan ez diete mugimendu horiek Hylandek proposatutako hurrenkerari jarraitzen. Mugimenduak hurrenkera zehatz horretan josita dauzkaten testuak bi izan dira (\% 2,02), ezagutza-eremu bakoitzean bana (Giza Zientzietako testuen arteko \% 3,8n eta Gizarte Zientzietako testuen arteko\% 1,3n). Hona hemen horren adibide den testu bat:

(I) Portaera agresiboan eragiten duten faktoreak ugariak dira: ingurunekoak, genetikoak, fisiologikoak eta sozialak. (P) Ikerketa honen helburua da aztertzea nola eragiten duten zenbait aldagai psikologiko eta biologikok eskola-adineko neska-mutilen jokabide agresiboan, kontuan hartuz sexuen arteko ezberdintasuna. (M) Horretarako, luzera erdiko bi fasedun ikerketa egin zen. Bi faseetan neska-mutilen portaera oldarkorra neurtu eta listulaginak bildu ziren hormona-mailak aztertzeko. Horrez gain, zenbait aldagai psikologiko analizatu ziren. (Pr) Emaitzek erakutsi zutenez, aldagai psikologiko (enpatia eta tenperamentua) eta biologikoen (testosterona eta kortisola) elkarreraginak neska-mutilen jokabide agresiboa azaldu zuen, baina elkarreragina desberdina izan zen bi faseetan. Hau da, faktore psikologiko eta biologikoen eragina jokabide agresiboan desberdina izan zen adinaren arabera. (C) Emaitza hauek agerian jartzen dute aldagai psikologiko eta biologikoen arteko elkarreragina ikertzearen garrantzia portaera agresiboa azaltzeko. [GR.18.07]

Hala ere, testu guztiak aztertu ondoren nabarmentzen den ezaugarria heterogeneotasuna da, 39 mugimendu-egitura identifikatu ditugu guztira. Bi ezagutza-eremuetan agertzen diren 9 mugimendu-egitura behatu ditugu eta, horiez gain, Giza Zientzietako laburpenen artean beste 9 eta Gizarte Zientzietako testuetan beste 21. Mugimendu-egitura horiek zeintzuk izan diren eta horietako bakoitza zein maiztasunekin agertu den ikus daiteke 6. taulan.

Esan dugun moduan, Hylandek proposatutako mugimendu-hurrenkerari jarraitzen dioten laburpenak bakanak dira gure corpusean, baina identifikatu ditugun egituren artean proposamen horretara gehien hurbiltzen den egitura bat (I-P-M-Pr) Gizarte Zientzietan gehien erabili diren egituren artean dagoela ikusi dugu (testuen arteko \% 13,6n). 7. taulan aurkezten ditugu corpuseko testuetan maizen erabili diren mugimendu-egiturak: 
6. TAula. Corpuseko testuetan identifikatutako mugimendu-Egiturak EZAGUTZA-EREMUKA (N ETA \%). ITURRIA: AUTOREEK SORTUA.

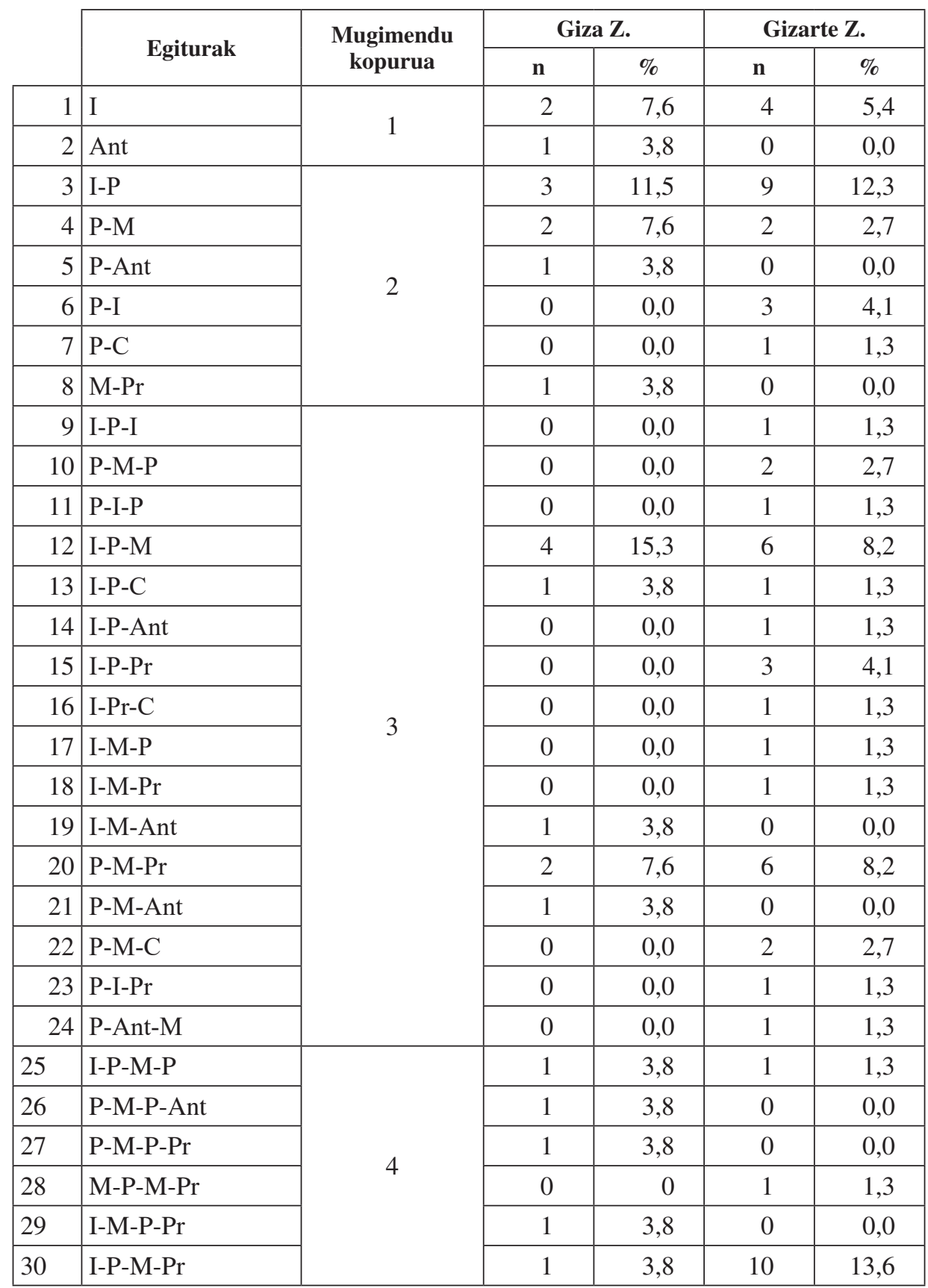




\begin{tabular}{|c|c|c|c|c|c|c|}
\hline & \multirow{2}{*}{ Egiturak } & \multirow{2}{*}{$\begin{array}{l}\text { Mugimendu } \\
\text { kopurua }\end{array}$} & \multicolumn{2}{|c|}{ Giza Z. } & \multicolumn{2}{|c|}{ Gizarte $\mathrm{Z}$. } \\
\hline & & & $\mathbf{n}$ & $\%$ & n & $\%$ \\
\hline 31 & I-P-Pr-C & \multirow{5}{*}{4} & 0 & 0,0 & 1 & 1,3 \\
\hline 32 & I-P-M-C & & 0 & 0,0 & 1 & 1,3 \\
\hline 33 & I-Ant-M-Pr & & 0 & 0,0 & 1 & 1,3 \\
\hline 34 & P-M-Pr-C & & 0 & 0,0 & 7 & 9,5 \\
\hline 35 & P-Ant-M-P & & 1 & 3,8 & 0 & 0,0 \\
\hline 36 & P-I-P-M-Pr & \multirow{4}{*}{5} & 0 & 0,0 & 1 & 1,3 \\
\hline 37 & M-P-M-Pr-Ant & & 0 & 0,0 & 1 & 1,3 \\
\hline 38 & I-P-M-Pr-C & & 1 & 3,8 & 1 & 1,3 \\
\hline 39 & I-M-P-Pr-C & & 0 & 0,0 & 1 & 1,3 \\
\hline & & & 26 & 100 & 73 & 100 \\
\hline
\end{tabular}

7. TAula. Corpuseko testuetan MAiZEN AgERTZEN DIREN MUGIMENDU-EGITURAK EZAGUTZA-EREMUKA. ITURRIA: AUTOREEK SORTUA.

\begin{tabular}{|l|c|c|}
\hline \multirow{2}{*}{ Testu kopurua } & Giza Zientziak & Gizarte Zientziak \\
\hline \multirow{2}{*}{$* 010$} & \multicolumn{2}{|c|}{ I-P } \\
\cline { 2 - 3 } & I-P-M & I-P-M-Pr \\
\cline { 2 - 3 } & \multicolumn{2}{|c|}{ I } \\
\cline { 2 - 3 } & \multicolumn{2}{|c|}{ P-M-Pr } \\
\cline { 2 - 3 } & P-M & I-P-M \\
\cline { 2 - 3 } & & P-M-Pr-C \\
\hline
\end{tabular}

Ikus dezakegunez, bi ezagutza-eremuetako testuen arteko \% 10 baino gehiagotan erabili da I-P mugimendu-egitura; eta, horrekin batera, kopuru beretsuan erabili dira Giza Zientzietan I-P-M egitura eta Gizarte Zientzietan I-P-M-Pr egitura. Corpuseko testuen arteko \% 5-10 tartean erabili dira bi ezagutza-eremuetan I mugimendua eta P-M-Pr mugimenduak; eta testuen kopurutarte horretan erabili dira P-M mugimenduak Giza Zientzietan eta I-P-M nahiz P-M-Pr-C mugimenduak Gizarte Zientzietako testuetan. Gainontzeko egitura guztiak corpuseko testuen arteko \% 5 baino gutxiagotan erabili dira (Giza Zientzietako testu bakarrean eta Gizarte Zientzietako 1, 2 edo 3 testutan).

Mugimendu erretorikoen egitura orokorrez gain, horien baitako mugimendu bakoitzaren zenbait jokabide behatu ditugu eta nabarmentzekoak iruditu zaizkigun datuak aurkeztuko ditugu jarraian. Datu zehatzak 8. taulan daude ikusgai: 
8. TAUla CORPUSEKo TESTUETAN IDENTIFIKATUTAKO MUGIMENDU BAKOITZAREN JOKABIDEARI BURUZKO DATUAK (AGERTUTAKO EGITURA KOPURUA ETA AGERPENPOSIZIOAREKIN LOTUTAKO XEHETASUNAK, N ETA \%). ITURRIA: AUTOREEK SORTUA.

\begin{tabular}{|c|c|c|c|c|c|c|c|}
\hline \multirow[t]{2}{*}{ Mugimenduak } & & \multicolumn{2}{|c|}{$\begin{array}{c}\text { Guztira } \\
\mathbf{n}=39\end{array}$} & \multicolumn{2}{|c|}{$\begin{array}{c}\text { Giza Zientziak } \\
\quad \mathrm{n}=18\end{array}$} & \multicolumn{2}{|c|}{$\begin{array}{c}\text { Gizarte } \\
\text { Zientziak } \\
\text { n=30 }\end{array}$} \\
\hline & & $\mathbf{n}$ & $\%$ & $\mathbf{n}$ & $\%$ & $\mathbf{n}$ & $\%$ \\
\hline \multirow[t]{2}{*}{ I } & Zenbat egituratan & 23 & 58,9 & 9 & 50 & 21 & 70 \\
\hline & 1. posizioan & $19 / 23$ & 82,6 & $8 / 9$ & 88,8 & $17 / 21$ & 80,9 \\
\hline \multirow[t]{2}{*}{$\mathrm{P}$} & Zenbat egituratan & 32 & 82,05 & 14 & 77,7 & 27 & 90 \\
\hline & $\begin{array}{l}\text { Lehen bi } \\
\text { posizioetan }\end{array}$ & $29 / 32$ & 90,6 & $13 / 14$ & 92,8 & $24 / 27$ & 88,8 \\
\hline \multirow[t]{2}{*}{ M } & Zenbat egituratan & 25 & 64,1 & 13 & 72,2 & 18 & 60 \\
\hline & $\begin{array}{l}\mathrm{P} \text { mugimenduaren } \\
\text { atzetik }\end{array}$ & $14 / 25$ & 56 & $9 / 13$ & 69,2 & $11 / 18$ & 61,1 \\
\hline \multirow[t]{2}{*}{$\operatorname{Pr}$} & Zenbat egituratan & 17 & 43,5 & 7 & 38,8 & 13 & 43,3 \\
\hline & Azken posizioan & $11 / 17$ & 64,7 & $5 / 7$ & 71,4 & $8 / 13$ & 61,5 \\
\hline \multirow[t]{3}{*}{$\mathrm{C}$} & Zenbat egituratan & 9 & 23,07 & 2 & 11,1 & 9 & 30 \\
\hline & Azken posizioan & 9/9 & 100 & $2 / 2$ & 100 & 9/9 & 100 \\
\hline & $\begin{array}{l}\text { Pr mugimendua } \\
\text { ere egotea }\end{array}$ & $5 / 9$ & 55,5 & $1 / 2$ & 50 & $5 / 9$ & 55,5 \\
\hline \multirow[t]{2}{*}{ Ant } & Zenbat egituratan & 10 & 25,6 & 6 & 33,3 & 4 & 13,3 \\
\hline & Azken posizioan & $7 / 10$ & 70 & $5 / 6$ & 83,3 & $2 / 4$ & 50 \\
\hline
\end{tabular}

Mugimendu bakoitzak identifikatutako egituretan daukan agerpenari dagokionez, bi ezagutza-eremuetako testuetan desberdintasunak daude baina, proportzionalki, alde horiek bat egiten dute aurretik mugimendu bakoitzaren agerpenari buruz aurkeztu ditugun datuekin.

Mugimendu bakoitzaren posizioari dagokionez, berriz, ez dugu alde handirik sumatu ezagutza-eremu batetik bestera. I (Sarrera) mugimendua lehen posizioan agertzen da mugimendu-egituren arteko \% 82,6n. P (Helburua) mugimendua lehen edo bigarren posizioan agertzen da egituren arteko \% 90,6n. M (Metodoa) mugimendua $\mathrm{P}$ mugimenduaren atzetik kokatzen da mugimenduen erdia baino gehiagotan (\% 56). Pr (Emaitzak) mugimendua azken posizioan agertzen da mugimenduen arteko \% 64,7n. C (Ondorioak) mugimendua azken posizioan kokatzen da agertzen den kasu guztietan, baina agertzen den kasuetan ez dirudi beharrezkoa Pr mugimendua ere egotea (testuen arteko \% 55,5ean 
daude bi mugimenduak). Azkenik, Antolaketa mugimendua da ezagutza-eremuen artean desberdintasun gehien erakusten dituena, bai agertzen den egiturakopuruari dagokionean (Giza Zientzietako egituren arteko \% 33,3n eta Gizarte Zientzietako egituren arteko \% 13,3n) eta bai mugimendu-egituretan azken posizioan kokatuta egoteari dagokionean (Giza Zientzietako egituren arteko \% 83,3n eta Gizarte Zientzietako egituren arteko \% 50en).

Laburbilduz, egindako analisiei esker, bi diziplinetan sortutako abstractak nolakoak diren jakiteko ikuspegi orokorra lortu da. Horretarako, gai orokorrei erreparatu zaie (hitz-kopurua, letra-kopurua, etab.), baita Hylanden ereduak (2000) ezartzen dituen mugimenduei ere. Horrela, mugimenduen kopurua, kokapena, eremuen araberako egitura prototipikoak eta abar zehatz-mehatz deskribatu dira. Orain, lortutako emaitzak interpretatzeko unea da.

\section{V.- EZTABAIDA ETA ONDORIOAK}

Esku-artean dugun lanean euskarazko idazketa akademikoari begira jarri gara. Eremu zabala izaki, gure begirada artikulu zientifikoen laburpenetara mugatu dugu. Zehazki, laburpen horien ezaugarri diskurtsiboen azterketa egin dugu, abstract horiek osatzen dituzten mugimendu erretorikoak aztertuz. Eta, horrekin batera, Giza Zientzietako laburpenen eta Gizarte Zientzietako laburpenen artean desberdintasunik ba al dagoen ikusi nahi izan dugu. Horrelako erkaketa-lanei dagokienez, euskal literatura akademikoaren gaineko ikerketak urriak baitira.

Lehenik eta behin, corpuseko testuen ezaugarri orokorrak ezagutzeko, $a b s$ tracten hitz kopuruari erreparatu diogu. Kaplan et al.-ek (1994) ezaugarri hori aztertu zuten ingelesez idatziriko laburpenez osatutako corpus batean eta ikusi zuten, oro har, abstractak 100-250 hitzez osatuta zeudela; APA-k (2020) esaten duenez ere, laburpenen luzerak 250 hitz ingurukoa izan behar du. Azterlan honetan ikusi dugunez, gure corpuseko testuak datu horien gutxienekoak baino baxuagoak dira (96,04 hitz). Nahiz eta, desbideratze estandarrek adierazten digutenez, testu batzuk luzeagoak ere izan. Kontuan izan behar dugu horretan eragin zuzena daukan aldagai bat: aldizkariak egileentzako aurkezten dituen oharrak. Kasu honetan, Uztaro aldizkariak eskatzen duenez, laburpenek 100150 hitzez osatuta egon behar dute, beraz, corpuseko testuak, batez bestean, ozta-ozta iristen dira aldizkariak eskatzen duen gutxienekora. Corpuseko laburpenetako esaldien luzerari dagokionez, ingelesezko idazketa akademikoa aztertzean MacDonald-ek (1990) ikusi zuen perpaus bakoitza 23,26 hitzez osatzen zela. Gure ikerketako datuak baxuagoak dira (Giza Zientzietako testuetan 19,35 hitz eta Gizarte Zientzietako testuetan 18,07 hitz), baina kontuan hartu behar dugu gure kasuan euskara izan dela testuetako hizkuntza eta MacDonald-en kasuan ingelesa. Horrenbestez, agerian geratzen da euskarazko testu akademikoek zer ezaugarri linguistiko dauzkaten aztertzeko beharra.

Lan honen helburu nagusia izan den bigarren galderari so egiteko, corpuseko laburpenen mugimendu erretorikoak behatu ditugu. Lanaren atal teorikoan gai honi buruzko hainbat ikerketa egin direla ikusi dugu. Gure kasuan, helburua 
ez da izan aurrez egindako ikerketa baten erreplika egitea eta gure azterketako ikergaia, testuingurua eta hizkuntza ez datoz bat atal teorikoan aipatutako ikerketa horietakoekin, beraz, ikuspuntu zientifiko batetatik, ez luke zentzurik konparaketak egiteak. Hala eta guztiz ere, zenbait datu alderagarriak iruditu zaizkigu. Esate baterako, Khansari et al.-ek (2016) eta Can et al.-ek (2016) hizkuntzalaritzaren esparruan gauzatutako ikerketan, Blancok (2017b) Gizarte Zientzien eremuan burututako azterketan eta Quintanillak (2016) hezkuntzaren alorrean egindako ikerlanean ikusi zuten artikulu zientifkoetako laburpenetako mugimenduetan ez zegoela homogeneotasunik. Gure ikerketako emaitzarik nabarmenena ere hori da, heterogeneotasuna.

Gure corpusa osatu duten testuei ezagutza-eremuka begiratuta, bai batean eta bai bestean mugimendu egituren kopuru oparoa ikusi dugu (Giza Zientzietako 26 testuetan 18 mugimendu-egitura, \% 6,9; Gizarte Zientzietako 73 testue$\tan 30$ mugimendu-egitura, \% 4,1). Ezagutza-eremuen alderaketari dagokionez, Samrajek (2008) eta Ibáñez et al.-ek (2015), besteen artean, zioten eremu akademiko bakoitzak bere interakzio-moduak dituela eta desberdintasunak egon ohi direla esparru horietako bakoitzean ekoizten diren testuen artean; baina Bhatti et al.-ek (2019) hizkuntzalaritzako eta literaturako abstractak alderatu ondoren ikusi zuten ez zegoela alde adierazgarririk bi diziplinen artean. Gure kasuan ere hori da ikusi duguna, beraz, ezin dugu ondorioztatu testuen izaera zehazterakoan diziplinak aldagai gisa funtzionatzen duenik.

Lan honetan zehar behin baino gehiagotan aipatu dugunez, ikerketaren oinarritzat Hylanden (2000) proposamena hartu dugu. Baina proposamen horretatik bereziki aldentzen diren zenbait ezaugarri identifikatu ditugu eta nabarmentzekoak iruditu zaizkigu. Lehenengoz, Hylandek proposatzen dituen mugimenduez gain beste mugimendu bat identifikatu dugu eta Antolaketa izena eman diogu. Corpuseko testuen arteko \% 10,1en agertzen da mugimendu hori. Bigarrengoz, corpuseko testuen arteko \% 6,06 I (Sarrera) mugimenduaz bakarrik daude osatuta. Hori gertatzearen atzean egon litezkeen arrazoien bila hasita, izan liteke laburpenak sortzen direnean testu-genero horren funtzioa zein den argi ez edukitzea. Alegia, teoriaren atalean esan bezala (Quintanilla 2016), laburpen baten funtzioa artikulu horren edukiei buruzko xehetasunak ematea da, irakurleak erabaki dezan artikulu osoa irakurri ala ez. Ikertzaile bat gai jakin bati buruzko bibliografiaren errebisioa egiten ari denean ezin du aurkitutako literatura guztia irakurri, eta galbahe lanak egiten ditu artikulu horietako bakoitzaren laburpenak. Baina laburpenak Sarrera mugimenduarekin bakarrik argitaratzen dituzten egileen kasuan, badirudi kezka dagoela ikerketaren funtsezko informazioa edo emaitzak aurreratzeko.

Hirugarrengoz, corpuseko testuetan gehien agertu den mugimendua $\mathrm{P}$ ( $\mathrm{Hel}$ burua) izan arren, mugimendu-egiturak aztertu ditugunean ikusi dugu P mugimendurik ez daukaten egiturak \% 17,9 direla. Horrek, honako zalantzak sorrarazten dizkigu: helbururik adierazten ez duen laburpen batek betetzen al du bere funtzioa? Alegia, bere helburu komunikatiboa betetzen al du? Berriro ere aurreko paragrafoan adierazi dugun ideiara garamatza honek.

Orain arte esandako guztiaren harira hainbat hausnarketa orokor bururatu zaizkigu. Hasteko, interesgarria izango litzateke ikerketa honetako emaitzak 
testuinguru berean garatutako beste ikerketa batzuen emaitzekin alderatzea baina, gaur gaurkoz, hori egitea ez da posible, euskararen unibertso hau aztertzeke baitago oraindik. Zentzu horretan, aurrekari falta dela eta, azterlan honetan lortutako emaitzek ikerketa-ildo berriak zabaltzeko aukera eman dezaketela uste izan dugu. Esate baterako, ikerketa honetako emaitzei begiratuta, artikulu zientifikoen laburpenak osatzen dituzten mugimendu-egituren heterogeneotasuna da ezaugarririk nabarmenena. Oihartzun gehien daukan ekoizpen akademikoa ingelesez egiten da (Laborde 2011) eta ingelesezko idazketa akademikoan abstract generoa garatzeko kanon zehatzak daude, dagoenekoz egonkortuta eta komunitate zientifikoaren aintzatespena jasota. Gauzak ez dira horrela gure testuinguruan: euskaraz egiten dugun idazketa akademikoan laburpenaren generoa oraindik finkatu gabe dagoela esan genezake.

Horrez gain, beste faktore batzuk ere eragin ahal izan dute euskarazko laburpenetan ikusi dugun heterogeneotasun horretan: batetik, euskaraz egiten den idazketa akademikoaren ibilbidea laburra dela esan genezake eta horren ondorio izan liteke oraindik testu-generoen egiturak egonkortu gabe egotea; bestetik, aldizkari zientifikoetan argitaratzeko jarraibideak ematen dituzte aldizkari horiek, baina egileentzako oharretan ez da eman ohi laburpenek izan beharreko egitura edo ezaugarriei buruzko zehaztapenik. Horren guztiaren berri izanda, ikusteke dago euskal komunitate zientifikoak zer egingo duen. Lehenengo urratsa gertatzen denaz jabetzea da eta horretan jarri nahi lukete bere alea esku-artean daukagun lanak eta ikerlerro honetan gauzatzen ari garen beste lanek. Behin egoeraz jabetuta, erabaki egin beharko da artikulu zientifikoetako testu-generoen kanonak zehazteak onurarik ekartzen al digun eta horren aurrean zer egin nahi dugun. Eta horretan berebiziko eragina izan dezakete aldizkarietan adierazten diren egileentzako oharrek; euskal kanonak sortu edo bateratu nahi baldin badira, hor egon liteke gakoa, Swalesek (2004) esandakoarekin bat eginez.

Euskal komunitate zientifikoa geroz eta formatuagoa dagoela esan genezake: geroz eta euskarazko doktorego-tesi gehiago egiten dira (Eusko Jaurlaritzako Kultura eta Hizkuntza Politika Saila d.g.) eta euskal komunitate zientifikointelektualaren datu-basea den Inguman euskal ekoizpen akademikoa oparoa dela ziurta dezakegu (https://www.inguma.eus/); horrek, berekin dakar euskara ez beste hizkuntzetan argitaratutako literatura irakurtzea eta hizkuntza horietan egiten den idazketa akademikoa eta testu-generoetako eginbideak ezagutzea, batetik, eta abstract generoaren funtzioa barneratzea, bestetik. Horrez gain, beste bi ideia: batetik, euskal komunitate zientifikoa osatzen dugun ikertzaileok behartuta gaude oso parametro zorrotzak dauzkaten egiaztapen zientifikoak eskuratzera eta, horretarako, ezinbestekoa da nazioartean prestijioa daukaten aldizkari nahiz argitaletxeetan argitaratzea (Isasi 2004, Apalategi 2017); eta, bestetik, euskarazko lanak (ere) argitaratzen dituzten aldizkari zientifikoak kalitate-irizpide horiek lortzeko prozesuetan sartzen ari direla dirudi (Boillos eta Bereziartua 2020). Horrekin guztiarekin lotura izan dezake testu-generoen egiturak bateratzeko eta egonkortzeko joerak. Blancok (2017a) hezkuntzaren esparruan egindako ikerketan ikusi zuen egituretan gero eta egonkortasun handiagoa dagoela eta ikusi egin beharko da gure testuinguruan ere horrela gertatzen den. 
Testuinguru honetan, badira interesgarriak eta emankorrak begitantzen zaizkigun zenbait ikerketa-esparru. Ikerketaren ikuspuntutik, euskarazko idazketa akademikoa oraindik aztertu gabeko ikergai joria delakoan gaude, bai alderdi diskurtsibotik begiratuta eta bai alderdi linguistikotik begiratuta. Interesgarria izango litzateke, beste hizkuntza batzuetan egiten den gisan, eremu akademikoan euskaraz sortzen diren ekoizpenen ezaugarri diskurtsiboak ezagutzea eta horietan erabiltzen den hizkuntzaren nondik norakoen jakitun izatea.

Artikulu zientifikoetako laburpenak ekoizten eta kontsumitzen dituztenei begira jarrita, interesgarria izango litzateke irakurlearen ikuspegia ezagutzea: bere itxaropenak betetzen al dira? Laburpenek beren funtzioa betetzen al dute? Eta baita laburpenak sortzen dituztenen ikuspegia ezagutzea ere: zein da euskal ikertzaileen modus operandia abstractak idazten dituztenean? Zeintzuk dira hartzen dituzten erabakiak eta zertan oinarritzen dira erabaki horiek hartzeko?

Amaitzeko, hezkuntzaren eremuari egingo diogu keinu. Unibertsitate mailako irakaskuntzan pixkanaka lekua hartzen ari dira ikasleak euskarazko idazketa akademikoan trebatzeko ekimenak. Baina oraindik egiteko asko dagoela esan genezake. Euskarazko idazketa akademikoaren irakaskuntzak unibertsitateko graduetan izan beharko lukeen —eta, gaur gaurkoz, ez daukan - tokia alde batera utzita, behar beste baliabide pertsonal eta material ez daudela iruditzen zaigu, ez irakasleon prestakuntzari dagokionez eta ez erabiltzeko materialei dagokienez (Bereziartua eta Boillos 2020). Esku-artean dugun lanaren gisakoek horretan lagun dezaketelakoan gaude.

\section{BIBLIOGRAFIA}

Al-Khasawneh, F.M. (2017) «A genre analysis of research article abstracts written by native and non-native speakers of English», Journal of Applied Linguistics and Language Research, 4(1), 1-13 or.

Alotaibi, H. (2015) «Metadiscourse in Arabic and English research article abstracts», World Journal of English Language, 5(2), 1-8 or. doi: https://doi. org/10.5430/wjel.v5n2p1

Al-Shujairi, Y. B.J., Ya'u, M. S. + Buba, J.A. (2016) «Role of moves, tenses, and metadiscourse in the abstract of an acceptable research article», Mediterranean Journal of Social Sciences, 7(2), 379-386 or. doi: https://doi. org/10.5901/mjss.2016.v7n2s1p379

American Psychological Association (2020) Publication manual of the American Psychological Association (7th ed.). doi: https://doi. org/10.1037/000016S-000

Ansarifar, A., Shahriari, H. + Pishghadam, R. (2018) «Phrasal complexity in academic writing: A comparison of abstracts written by graduate students and expert writers in applied linguistics», Journal of English for Academic Purposes, 31, 58-71 or. doi: https://doi.org/10.1016/j.jeap.2017.12.008 
Apalategi, J. (2017) «Giza eta Gizarte Zientziak eta Pedagogia euskaraz», Uztaro, $100+, 21-26$ or. doi: https://bit.ly/39g0Dgy

Artetxe, K. (2013) Komunitate zientiko euskalduna. Azterketa historikoa eta bibliometrikoa (Doktorego tesia), UPV/EHU.

Bakhtin, M. (1979) «El problema de los géneros discursivos». Bakhtin, Mikhail, Estética de la creación verbal, Mexiko, Siglo XXI, 248-293 or.

Bereziartua, G. + Boillos, M.M. (2020) «Laburpen zientifikoen izaera diskurtsiboa: Ikastorratza aldizkariaren azterketa», Ikastorratza. Didaktikarako e-aldizkaria, 25, 179-207 or. doi: https://doi.org/10.37261/25_alea/7

Bhatia, V. (1993) Analyzing Genre. Language Use in Professional Settings, Harlow, Longman.

Bhatti, I.A., Mustafa, S. + Azher, M. (2019) «Genre analysis of research article abstracts in Linguistics and Literatura: a cross disciplinary study», International Journal of English Linguisticas, 9(4), 42-50 or. doi: https://doi. org/10.5539/ijel.v9n4p42

Blanco, C.E. (2017a) «Cambio y estabilidad en resúmenes de una revista venezolana de educación (1997-2016)», Educação Unisinos, 21(2), 243-251 or. doi: https://doi.org/10.4013/edu.2017.212.13

Blanco, C.E. (2017b) «Discurso académico en Educación: resúmenes de artículos de ocho revistas especializadas venezolanas», Revista de Pedagogía, 38(103), 58-81 or. doi: https://doi.org/10.15517/rfl.v31i1.4414

Boillos, M.M. + Bereziartua, G. (2020) «Euskara eremu zientifikoan: giza eta gizarte zientziei buruzko aldizkarietako laburpenen azterketa kuantitatiboa (2010-2019)», Fontes Linguae Vasconum, 129, 141-178 or. doi: https://doi. org/10.35462/FLV129.5

Can, S.; Karabacak, E. + Qin, J. (2016) «Structure of Moves in Research Article Abstracts in Applied Linguistics», Publications, 4(23). doi: https://doi. org/10.3390/publications4030023

Darabad, A. M. (2016) «Move analysis of research article abstracts: A crossdisciplinary study», International Journal of Linguistics, 8(2), 125-140 or. doi: https://doi.org/10.5296/ijl.v8i2.9379

Dos Santos, M. (1996) «The Textual Organization of Research Paper Abstracts in Applied Linguistics», Text \& Talk, 16(4), 481-499 or. doi: https://doi. org/10.1515/text.1.1996.16.4.481

El-Dakhs, D.A.S. (2018) «Comparative genre analysis of research article abstracts in more and less prestigious journals: linguistics journals in focus», Research in Language, 16 (1), 47-63 or. doi: https://doi.org/10.2478/rela2018-0002

Eusko Jaurlaritzako Kultura eta Hizkuntza Politika Saila. (d.g.) Euskarazko doktorego-tesiak. Kultura eta hizkuntza Politika Saila, Eusko Jaurlaritza. 
https://www.euskadi.eus/euskarazko-doktorego-tesien-sarrera/web01a3tesiak/eu/ helbidetik berreskuratua.

Friginal, E. + Mustafa, S.S. (2017) «A comparison of US-based and Iraqi English research article abstracts using corpora», Journal of English for Academic Purposes, 25, 45-57 or. doi: https://doi.org/10.1016/j. jeap.2016.11.004

Gibaldi, J. (2008) MLA style manual and guide to scholarly publishing, New York, MLA Publications.

Hyland, K. (2000) Disciplinary Discourse: Social Interactions in Academic Writing, Michigan, Longman.

Ibáñez, R., Moncada, F. + Santana, A. (2015) «Variación disciplinar en el discurso académico de la Biología y del Derecho: un estudio a partir de las relaciones de coherencia», Onomázein, 32, 101-131 or. doi: https://doi. org/10.7764/onomazein.32.6

Isasi, X. (2004) «Unibertsitario euskaldunen egoera zaila», Bat: Soziolinguistika aldizkaria, 50, 131-139 or. doi: https://bit.ly/2WOKg86

Kaplan, R.B. (1966) «Cultural thought patterns in intercultural education», Language Learning. 16, (1-2), 1-20 or. doi: https://doi. org/10.1111/j.1467-1770.1966.tb00804.x

Kaplan, R.B., Cantor, S., Hagstrom, C., Kamhsi-Stein, L.D., Shiotani, Y., + Zimmerman, C.B. (1994) «On abstract writing», Text, 14(3), 401-426 or. doi: http://doi.org/10.1515/text.1.1994.14.3.401

Khansari, D., Chan, S.H., Chan, M. Y. + Tan, H. (2016) «Regularities and Irregularities in Rhetorical Move Structure of Linguistics Abstracts in Research Articles», 3L: The Southeast Asian Journal of English Language Studies, 22 (1), 39-54 or. doi: http://doi.org/10.17576/3L-2016-2201-04

Laborde, J. (2011) «The evaluation of researchers and the future of Latin American scientific journals». Cetto, Ana María + J. O. Alonso, Jose Octavio, Calidad e Impacto de la revista Iberoamericana, Mexiko, UNAM, 59-79 or., http://www.latindex.unam.mx/librociri helbidetik berreskuratua.

Lores, R. (2004) «On RA abstracts: From rhetorical structure to thematic organization», English for Specific Purposes, 23, 280-302 or. doi: https://doi. org/10.1016/j.esp.2003.06.001

MacDonald, S.P. (1990) «The literary argument and its discursive conventions». Nash, Walter, The Writing Scholar. Studies in academic discourse, Newbury Park, Sage Publications, 31-62 or.

Menezes, C. A. (2013) «A comparative study of textual and rhetorical features of abstracts written by expert and novice writers», A Palavrada, 3, 10-18 or.

Modern Language Association (2016) MLA Handbook (8th Edition), New York, MLA. 
Oneplee, J. (2008) Genre analysis of scientific abstracts: A comparative study of Science and Nature journals, Master's thesis at Mahhidol University, Thailand. http://mulinet11.li.mahidol.ac.th/thesis/2551/cd420/4936532.pdf helbidetik berreskuratua.

Otegi, A., Imaz, O., Díaz de Ilarraza, A., Iruskieta, M. + Uria, L. (2017) «ANALHITZA: a tool to extract linguistic information from large corpora in Humanities research», Procesamiento del Lenguaje Natural, 58, 77-84 or.

Piqué-Noguera, C. (2012) «Writing business research article abstracts: A genre approach», Ibérica, 24, 211-232 or.

Quintanilla, A. (2016) «La organización retórica del resumen o abstract del artículo de investigación en educación», Estudios Pedagógicos, 42(2), 286-298 or. doi: https://doi.org/10.4067/S0718-07052016000200016

Samraj, B. (2008) «A discourse analysis of master's theses across disciplines with a focus on introductions», Journal of English for Specific Purposes, 7, 55-67 or. doi: https://doi.org/10.1016/j.jeap.2008.02.005

Seyed, P.S. + Shamala, P. (2019) «Rhetorical move analysis in political science research article abstracts in English in Iranian journals», Journal of Language and Communication, 6(1).

Swales, J. M. (1990) Genre Analysis. English in Academic and Research Settings, Cambridge, Cambridge University Press.

Swales, J. M. (2004) Research Genres: Exploration and Applications, Cambridge, Cambridge University Press.

Tankó, G. (2017) «Literary research article abstracts: An analysis of rhetorical moves and their linguistic realizations», Journal of English for Academic Purposes, 27, 42-55 or. doi: https://doi.org/10.1016/j.jeap.2017.04.003

Tseng, F. (2011) «Analysis of Move Structure and Verb Tense of Research Article Abstracts in Applied Linguistics Journals», International Journal of English Linguistics, 1(2), 27-39 or. doi: https://doi.org/10.5539/ijel.v1n2p27

Weissberg, R. + Buker, S. (1990) Writing Up Research. Experimental Research Report Writing for Students of English, New Jersey, Prentice Hall Regents.

Zanina, E. (2017) «Move structure of research article abstracts on Management: Contrastive study (the case of English and Russian)», Journal of Language and Education, 3(2), 63-72 or. doi: https://doi.org/10.17323/2411-73902017-3-2-63-72 